\title{
Mediating distributive politics: political alignment and electoral business cycle effects on municipality financing in Greece
}

\section{Anastasios Kitsos $^{1}$ (D) $\cdot$ Antonios Proestakis ${ }^{2}$ (D)}

Received: 12 December 2019 / Accepted: 1 December 2020 / Published online: 29 January 2021

(c) The Author(s) 2021

\begin{abstract}
We examine the role of political alignment and the electoral business cycle on municipality revenues in Greece for the period 2003-2010. The misallocation of resources for political gain represents a waste of resources with significant negative effects on local growth and effective decentralization. The focus of our analysis is municipality mayors since they mediate the relationship between central government and voters and hence can influence the effectiveness of any potential pork-barrelling activity. A novel panel data set combining the results of two local and three national elections with annual municipality budgets is used to run a fixed-effects econometric model. This allows us to identify whether the political alignment between mayors and central government affects municipality financing. We examine this at different stages of local and national electoral cycles, investigating both direct intergovernmental transfers (grants) and the remaining sources of local revenues (own revenues, loans). We find that total revenues are significantly higher for aligned municipalities in the run-up to elections due to higher intergovernmental transfers. We also find evidence that the 2008 crisis has reduced such pork-barrelling activity. This significant resource misallocation increases vertical networking dependency and calls for policy changes promoting greater decentralization and encouraging innovation in local revenue raising.
\end{abstract}

Spplementary Information The online version contains supplementary material at https://doi. org/10.1007/s00168-020-01038-7.

Anastasios Kitsos

a.kitsos@bham.ac.uk

Antonios Proestakis

antonios.proestakis@ec.europa.eu

1 City-REDI, Birmingham Business School, University of Birmingham, Birmingham B15 2TT, UK

2 Joint Research Centre, European Commission, Rue du Champ de Mars 21, 1050 Brussels, Belgium 
JEL Classification $\mathrm{D} 72 \cdot \mathrm{H} 72 \cdot \mathrm{H} 77 \cdot \mathrm{R} 50$

\section{Introduction}

We study the effect of political partisanship and the electoral business cycle on municipality financing under the prism of distributive politics in Greece. The country has one of the most fiscally centralized multi-level governance systems in Europe, with a historic pattern of underperformance in governance indicators (Kaufmann et al. 2013) and clientelistic practices (Lyberaki and Tsakalotos 2002). Despite this, little is known to date as to how the political alignment of upper- and lower-tier governments and the electoral business cycle affect municipality finances and vertical networking dependency (Chorianopoulos 2012) among these Greek government tiers.

Central to our analysis is the mayor of each municipality, the contact person between the voter and the central government. He/she is physically the closest person to the voter and the one who can effectively lobby (Borck and Owings 2003) or mediate central government attempts to engage in electoral politics (Bracco et al. 2015). The outcome of this relationship is hypothesized to be larger government grants flowing into politically aligned municipalities. Hence, we analyse the effect of a mayor's political affiliation on a municipality's annual budget. Beyond the direct transfers from central government to municipalities (in the form of grants), we adopt a more holistic approach for considering the local budget by analysing the indirect effects on the remaining two sources of local funding (own revenues and loans). Simultaneously, we consider at which stage of the electoral cycle these effects take place, with the expectation that electoral politics will be more prevalent in the runup to national and local elections.

Distributive politics represent a resource misallocation problem in many countries. It can challenge the equity, efficiency or countercyclical targets that are used to justify public policy intervention (Musgrave 1959) and may have long-lasting growth prosperity and inequality (Livert and Gainza 2018; López et al. 2017; Luca 2018) as well as quality of governance (Brollo et al. 2013) effects. Consequently, several studies examine distributive politics in different countries and regularly find that electoral considerations do play a role in the allocation of government resources either to 'core' or to 'swing' voters (Golden and Min 2013).

Multi-level governance systems and the time to the next election add new dimensions on examining how resources are misallocated in order to influence election outcomes. Politically aligned tiers of government may improve the efficiency of distributive politics practices (Bracco et al. 2015). This in turn draws more funds into a locality with significant implications for vertical intergovernmental dependency and the financing of non-aligned local governments (Chorianopoulos 2012; Solé-Ollé and SorribasNavarro 2008). Engagement in such tactical distribution of resources may in turn be influenced by the stage of the electoral business cycle since incumbent governments are expected to be more active in clientelistic practices in the run-up to elections (Veiga and Veiga 2007). Given its centralized political landscape and its prominence among the underperforming European democracies in corruption and perceived government 
efficiency measures, electoral considerations in Greek intergovernmental financing have been largely unexplored.

This study aims at filling this gap by focusing on both the total municipal revenues and their disaggregation into grants, loans and own revenues in Greece. The empirical estimation benefits from exogenously determined, simultaneous local elections and by using a novel panel data set that combines electoral results in national (parliamentary) and local elections, as well as local authority finances for the period 2003-2010. This allows us to observe changes of political affiliation at both layers of government. Moreover, applying a fixed-effects econometric model, we neutralize the effect of unobserved time-invariant differences between municipalities and focus on the effect of mayors' political affiliation at different stages of local and national electoral cycles.

It contributes a new dimension to existing studies (Lambrinidis et al. 2005; Rodríguez-Pose et al. 2016a, b) by investigating the roles of political alignment and the national and local electoral business cycle on municipality financing in Greece. It uses intergovernmental transfers at a more granular level than NUTS 3 regions (municipality level), which are decided annually and are not subject to the significant lags observed for investment funding. By using this approach, we can identify whether political alignment and the electoral cycle are significant mediators in the allocation of intergovernmental grants. Additionally, the paper offers an insight into how the 2008 crisis has affected distributive politics as the country entered one of its most turbulent (politically and financially) periods of its recent history. To the best of our knowledge, it is the first time a paper is addressing the significance of these factors simultaneously in the Greek context using a fixed-effects approach.

Our findings suggest that there is a substantial misallocation of government grants towards politically aligned municipalities and are novel in finding this happens in the run-up to both national and local elections. This increases the vertical dependency of local on national government (Chorianopoulos 2012; Psycharis et al. 2016), and, even though the crisis appears to have reduced this type of resource misallocation, it calls for a change in municipality financing policy. It adds to the existing debates on decentralization and dependence (Balaguer-Coll et al. 2010) and argues that, irrespective of efficiency gains, moving away from intergovernmental grants could help minimize porkbarrelling diseconomies. The results are confirmed by a range of robustness tests and are relevant to similar fiscally centralized, multi-level governance systems as well as the relatively recently reformed Central and Eastern European countries, which suffer from comparable government inefficiencies.

The paper is structured as follows. Section two reviews research on the mediators of distributive politics. This is followed by an outline of the evolution of the local government structure in Greece since the 1970s, as well as the data and methodology. Section five discusses the results of the econometric examination before the final section presents the conclusions and avenues for further study. 


\section{The mediators of distributive politics}

The paper is informed by and contributes to three strands of the distributive politics literature. First is the discussion of the core vs swing voter hypotheses that have been developed to explain electoral influences in the allocation of public goods. In the core voter hypothesis, information asymmetry on individuals' voting intentions means that risk-averse politicians will target resource allocation to voters they know will support them (Cox and McCubbins 1986). As a result, funds will be channelled towards a party's core voters since it reflects a less risky investment leading to traditional machine politics. In contrast, the swing voter hypothesis suggests that voters without strong partisan alignments require less resources for politicians to secure their votes (Dixit and Londregan 1996; Lindbeck and Weibull 1987). Hence, investment in swing voters is more productive since it can return more voters towards the incumbent party.

Support for both propositions has been found in a range of empirical studies across different countries. The 'swing' hypothesis has been evidenced by Dahlberg and Johansson's (2002) work on Swedish municipalities, Castells and Solé-Ollé (2005) and Solé-Ollé (2013) for infrastructure investments in Spanish regions, Case (2001) on block grants in Albania and Gonschorek et al. (2018) on discretionary grants in Indonesia. The 'core' voter hypothesis is supported by the findings of Rodríguez-Pose et al. (2016a, b) that investment is directed in 'core' voting NUTS3 regions in Greece, Ansolabehere and Snyder's (2006) work on intergovernmental transfers in the USA and the study of German discretionary grants by Kauder et al. (2016). Less clear-cut, Luca and Rodríguez-Pose (2015) find that in Turkey, spending was directed to 'core' voters. However, they also find that socio-economic conditions have been the main determinant of these allocations, primarily directed to the most developed areas for efficiency considerations.

The second strand of the literature that is relevant refers to the effect of political business cycles on the distribution of governmental grants and local government spending decisions. Nordhaus (1975) produced the first model of adaptive expectations where voters formed a decision to vote based on the most recent information they had. The theory predicts that governments will engage in looser fiscal and monetary policies closer to elections in order to secure re-election. The model has been further developed by Rogoff and Sibert (1988) and Rogoff (1990) to adopt rational expectations and the visibility of spending (instead of the size), maintaining however its focus on the cyclicality of effects (Veiga and Veiga 2007).

Confirming the existence of political business cycles, Shi and Svensson (2006) find that during 1975-1995 national fiscal deficits, as a share of the GDP, rose in the run-up to national election in a number of countries with the result driven mainly by developing rather than developed countries. Their study follows the Nordhaus (1975) model, whilst Drazen and Eslava (2010) utilize a more nuanced approach where the business cycle affects the composition of spending towards more visible expenses rather than the total expenditure. Finally, Bartolini and Santolini (2012) find that yardstick competition is prevalent among municipalities 
in Italy in pre-election periods, whilst Dubois and Paty (2010) delve further into what characteristics matter in yardstick competition among French municipalities.

The third and most relevant, to this paper, strand of the literature concerns the evidence of political distortions in the allocation of government grants on the basis of alignment among different government tiers (Diaz-Cayeros et al. 2007; Grossman 1994). From a bottom-up approach, the work of Borck and Owings (2003) suggests that it is the lobbying efforts of local governments that attracts higher shares of intergovernmental grants and that political and geographical distance from central government influence these efforts. The authors find support of their propositions by examining county-level allocations in 5-year periods between 1977 and 1992 in California. On the contrary, Bracco et al. (2015) offer a theoretical framework where public goods provision is a signal of competence whilst grant allocations are unobservable to the median voter. In these conditions, national governments allocate greater funds to politically aligned lower-tier governments in order to strengthen their competency outlook. These effects are expected to be higher in the run-up to local elections and the authors confirm their hypotheses using intergovernmental grants to Italian municipalities during 1998-2010.

In both these approaches, the outcome remains the same. Politically aligned local governments receive a disproportionate amount of intergovernmental grants that cannot be justified by either equity or efficiency considerations. In the last few years, there is mounting evidence confirming these findings. Brollo and Nannicini (2012) identify electoral influences in the allocation of discretionary federal grants to municipalities on infrastructure development in Brazil. The effect is mainly driven by reduced allocations to non-partisan municipalities in the run-up to local elections. Livert and Gainza (2018) find increased allocations of investment from the central government to aligned municipalities before local elections in Chile during 2004-2014. Solé-Ollé and Sorribas-Navarro (2008) find similar alignment effects in municipality grants in Spain during 1993-2003 and Bracco et al. (2015) for Italian municipalities during 1998-2010.

It is worth noting that other factors have also been found to affect the alignment channel of intergovernmental grants. Gonschorek et al. (2018) and Dalle Nogare and Kauder (2017) highlight the impact of term limits on electoral politics in Indonesia and Italy, whilst Carozzi and Repetto (2016) find birthplace bias alongside re-election considerations in the distortion of intergovernmental grants by Italian parliamentarians. Golden and Min (2013) provide a range of studies that consider further factors such as cultural and ethnic favouritism. Due to the relatively homogenous (ethnically and culturally) population of Greece, these factors are unlikely to be at play for this study. Similarly, the lack of term limits and single-member-only electoral districts make it impossible to consider factors such as the ones by Gonschorek et al. (2018), Dalle Nogare and Kauder (2017) and Carozzi and Repetto (2016).

The discussion above suggests that the distributive politics literature would be incomplete without considering factors such as the intergovernmental political alignment and the stage of the political business cycle, especially in a country like Greece with a long-established local governance tier and a tradition of clientelism. This paper addresses these topics by examining the effects of alignment and the electoral business cycle on municipality financing considering both national and 
local elections. It aims to add evidence to the literature on the effects of partisan alignment in conjunction with political business cycle considerations in a country that has received very little research attention compared to its negative reputation on corruption metrics.

\section{The Greek case}

As with most spatial configurations, the evolution of multi-level governance in Greece reflects a series of socio-economic processes. It resembles the distributional dynamics of power and responsibility from the national to supranational and sub-national levels observed in other EU countries (Chorianopoulos 2012). At the national level, there has been an attempt in the last 40 years to modernize the country's local governance system. However, most of these efforts were primarily top-down cost-cutting exercises, whilst Greek politics retained past practices of clientelism.

After a 30-year long period of post-war instability, what was coined the third Greek Republic has been established in the mid-1970s. Local government before that was largely constrained and directed from upper-tier government levels with centrally appointed mayors and limited technical capacity. The restructuring of local governance, which included directly elected local representatives, was one of the first acts of the newly formed republic and even preceded the constitutional changes that re-established democracy (Chorianopoulos 2012). The main purpose for empowering municipalities was to improve service provision and have a better understanding of local needs and capabilities.

However, establishing a new layer of government was primarily a centrally managed exercise that did not escape the politicization of the process by the two main governing parties (Conservative and Social Democrats) and the formation of vertical intergovernmental dependencies. These dependencies allowed central government to use municipalities for machine politics and clientelistic practices (Chorianopoulos 2012; Lyberaki and Tsakalotos 2002).

By the mid-1990s, the 5775 municipalities created during this first-wave governance structure were deemed inefficient in service provision and cost-ineffective. The new spatial plan came to be known as the 'Kapodistrias' local government structure and involved the division of Greece into 1034 municipalities led by directly elected mayors. The process of amalgamation was, once more, led by upper-tier government levels and despite reducing the number of municipalities, it largely failed to transfer revenue-raising power to municipalities, maintaining the vertical networking dependency characteristics of its predecessor (Chardas 2014; Chorianopoulos 2012).

The inefficiencies of the 'Kapodistrias' plan, coupled with the 2008 crisis in Greece and the Eurozone, led to further amalgamation. The 'Kalikratis' plan had provisions for the creation of 325 municipalities in 2010. The evidence so far suggests that this was mainly motivated by the need to reduce costs due to austerity views that prevailed at the national and supranational organizations involved in the Greek bailout (Chardas 2014). 
Despite the above evidence and for all its bad reputation, Greece has been largely under-examined in the literature of distributive politics. It was only recently that researchers investigated political considerations in the allocation of public investment. Lambrinidis et al. (2005) study the allocation of public infrastructure investments in 51 Greek NUTS 3 regions for 1982-1994 and find support for the electoral business cycle hypothesis (Nordhaus-type) but not pork-barrelling. Using the same geography but all public investment expenditure for the period 1974-2009, Rodríguez-Pose et al. (2016a) identify that funding was directed towards core voters when the 'Socialist' party (PASOK) was in government and to swing constituencies when the 'Liberals' (ND) were in office. These studies provide evidence of the political distortions in the allocation of public investment at the NUTS 3 (prefecture) level. The political variables they use refer to the incumbent party's national electoral margins in each region.

However, these papers do not account for the partisan alignment between grantor and grantee (see discussion in previous section) and hence do not offer any insights on the role of political alignment on mediating clientelism practices. The only exception is Psycharis et al. (2016) who use political alignment as an explanatory factor for explaining differences between municipalities on the level of autonomy they enjoy with regards to their revenues and expenditure. ${ }^{1}$

In addition, municipalities sit below the NUTS 3 regional level and are host to polling stations for which (national) election results are known. These two characteristics together with the fact that most of local government funding comes from central government sources suggest that municipalities could be a very useful tool at the hands of incumbent governments which, with the help of politically aligned mayors, can target specific segments of a constituency (NUTS3 region). By being closer to the voter, the local government level benefits from increased information on local needs and can assist the more efficient provision of public goods and services. However, its ties to the national government and party system render it a useful tool for targeting these goods and services for electoral reasons instead of equity or efficiency ones.

Misallocating resources through local government financing represents a more immediate transfer compared to public investment. The latter often takes years of planning, and there is a significant lag between allocation and realization, suggesting that it could serve more long-term strategies than the allocation of municipal funds. ${ }^{2}$

\footnotetext{
1 Our study is different in that it focuses on the direct effect of alignment and the political business cycle on the allocation of grants as well as own revenues and loans. In this way, it is possible to offer insights on the vertical dependency and the channelling of resources from the central government to municipalities for electoral purposes. Moreover, the fixed-effects examination allows us to identify the effect of partisanship by comparing a municipality when it is aligned to itself when it is not. Psycharis et al. (2016) use the relative size of grants to expenditure and own revenues to total revenues to define the level of autonomy of different municipalities based on a range of time-invariant and time-variant characteristics. Their random-effects specification compares municipalities to each other and provides an indication on the composition of revenues (and hence, autonomy).

2 An illustrative example of this is the underground of the city of Thessaloniki, originally proposed in the 1910 s, re-planned in 1988 with initial construction starting in 1989. At the time of writing, the underground is expected to have its first trip in mid-2023.
} 
The study focuses on the 'Kapodistrias' plan and in particular in the years 2003-2010. The time period provides a sufficient number of elections (local and national) and reflects an era of (predominantly) uninterrupted growth which came to an end in 2010 with the Greek bailout program and control of the county's expenditure by its funders (Chardas 2014). Financing local government during this period is largely influenced by the central autonomous funds (KAP) (introduced in the late 1980s by law 1828/1989) that required that shares of several taxes such as income and value added tax are ring-fenced to fund local government (Psycharis et al. 2016). Approximately $60 \%$ of municipality funding comes from central government.

\section{Data and research design}

\subsection{Data}

The data used for the investigation of political considerations in the allocation of funding from the state to municipalities combine electoral results (at both the state and local government level) with budget information at the municipal level for the period 2003-2010. Three parliamentary elections (2004, 2007 and 2009) and two local elections (2006 and 2010) were held during this period. These data are supplemented by local authority fiscal data, outlining municipality revenues and their breakdown into own revenues, grants and loans.

\subsection{National and local elections}

Local elections are held exactly on the same day of the year by all municipalities, defining a clear electoral period for all candidates. The local and parliamentary elections' data set $^{3}$ used in our analysis reports the political affiliation of the winners in the relevant elections. The data on mayors' affiliation predominantly cover the most populous municipalities. However, our sample still accounts for the majority of the population and government transfers.

For example, in 2003, the 199 municipalities with affiliation information account for 7.17 million citizens (about two-thirds of the total population of Greece at that time) and correspond to more than two-thirds of the total local budget of all municipalities. ${ }^{4}$ Similar are the sample sizes for the rest of the years in our data. Thus, municipalities with no available data on affiliation are omitted from the remaining analysis.

Figure 1 shows the electoral timeline and the number of aligned and nonaligned mayors with the national government during the period 2003-2010. In

\footnotetext{
3 Source: Greek Ministry of Internal Affairs. This was chosen as the most reliable source of information with sample sizes ranging from 1001 municipalities in 2010 to 1033 in 2007-2009 out of a total of 1034.

4 Data from 2006 local elections (not shown here) yielded similar results in respect to affiliation frequency and population; about 169 municipalities containing 6.81 million citizens were reported in Ministry's website as affiliated.
} 
the parliamentary elections of 2004 and 2009, the opposition party won and the government changed during the respective calendar year; since the focus of this study is the local budget that is approved in the parliament at the end of each calendar year, we consider that the budget follows the affiliation of the incumbent government at the end of each last calendar year and the beginning of each current year (i.e. PASOK (henceforth Social Democrats) for 2004 and ND (henceforth Conservatives) for 2009). For the remaining years, the active incumbent party is considered the full controller of the government budget each year. Consequently, in the period between 2005 and 2009 (blue part of the timeline), Conservatives is considered the incumbent party and therefore mayors originating or supported by Conservatives are consider aligned (blue bar). In the same period, non-aligned mayors supported either by Social Democrats (green (dashed) part of the two-coloured bar) or any other smaller opposition party (yellow (light and striped) part of the two-coloured bar). Accordingly, for the years 2003, 2004 and 2010 when Social Democrats was governing (green part of the timeline), aligned mayors were those originating or supported by Social Democrats (green (dashed) colour bar) and non-aligned, those supported by either Conservatives (blue part of the two-coloured bar) or any other small opposition party (yellow (light and striped) part of the two-coloured bar). As can be seen below, the variables of interest will be based on the data above and will capture the effect of political alignment and the electoral business cycle on municipality funding. We apply a fixed-effects econometric model to neutralize the effect of unobserved time-invariant differences between municipalities and focus on the impact of mayors' political affiliation on the municipality budget at two different instances:

(a) when a municipality switches from aligned to non-aligned and vice versa due to a change in the national government

(b) when a municipality switches from aligned to non-aligned and vice versa (e.g. change of mayor), whilst the national government remained the same.

\subsection{Municipality finances}

The local budget data set $^{5}$ contains analytical information on the revenues (regular and extraordinary) of all municipalities, annually for the period 2003-2010. We group these subcategories into three principal revenue categories which, together with total revenues, are the dependent variables of the analysis: grants, own revenues and loans. ${ }^{6}$ In Fig. 2, we show the annual data of these three revenue groups together with the total annual revenues (in billion $€$ ) of all affiliated (pooled) municipalities.

\footnotetext{
5 Source: Hellenic Statistical Authority for 2003-2009 and the Ministry of Internal Affairs for 2010.

6 Revenue sub-categories (and the corresponding code used by Hellenic Statistical Authority) OWN REVENUES: Income from (01) Fixed assets, (02) Current assets, (03) User fees and rights, (04) User fees and Services, (05) Taxes, (07) Other regular revenues, (11) the sale of fixed and current assets, (14) sponsorships, charities and heritages, (15) Penalties and fines, (16) Other extraordinary Revenues, (21) Regular and (22) Extraordinary revenues from past years; GRANTS: (06) Regular Grants for operational expenses, Extraordinary Grants for (12) operational expenses, (13) for Investment; LOANS: (3) loans.
} 


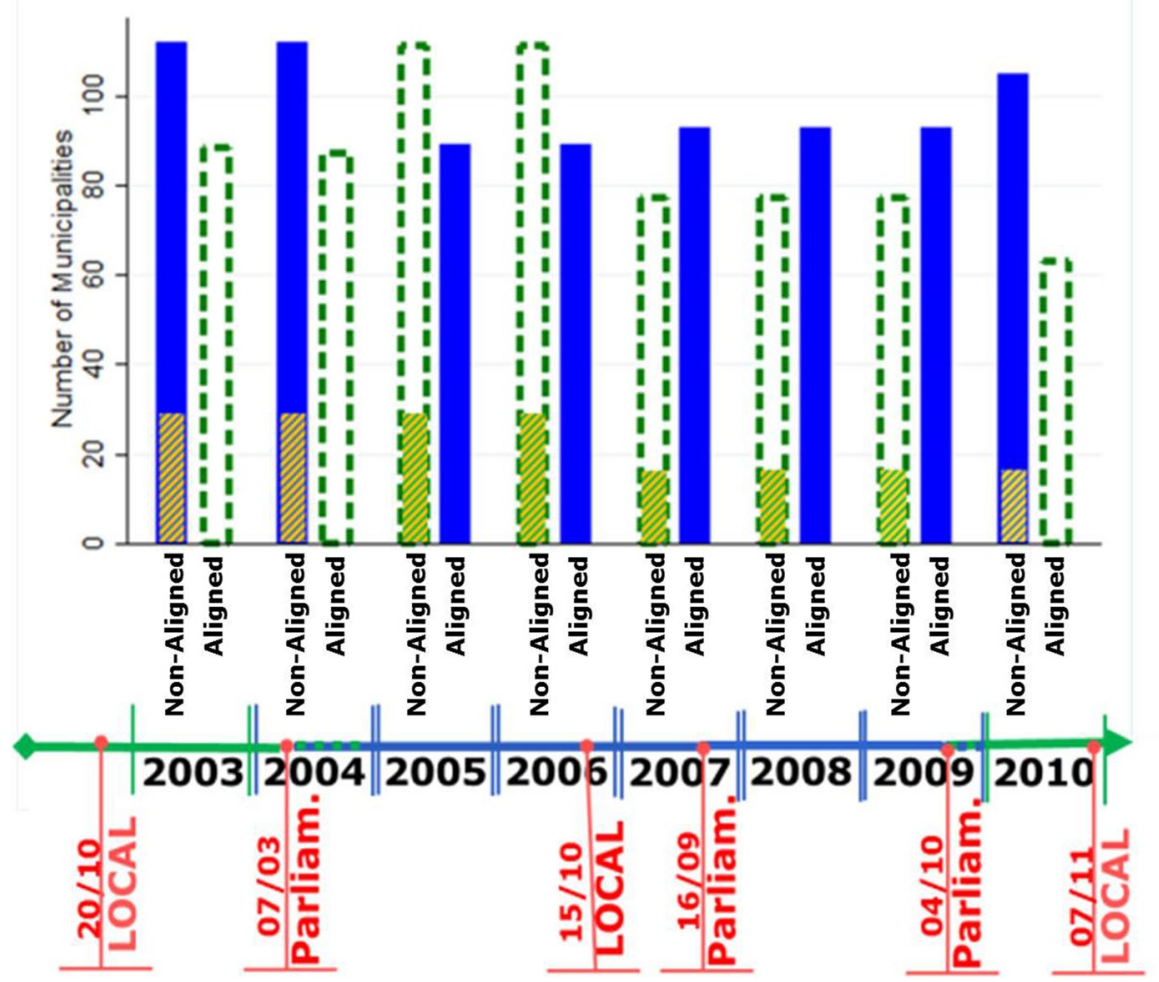

Fig. 1 Number of municipalities by alignment across the electoral time line

There are eight actual data points (one for each year) that are connected with a line to highlight the overall trend. The data are also projected to the electoral time line which is also approximating the dates of the parliamentary and local elections. At first glance, we can observe that government grants are on average the principal source of municipality revenues, reaching in 2009 about 2.52 billion $€$ which corresponds to the $59.8 \%$ of the total budget.

The intergovernmental grants to municipalities involve transfers (regular or extraordinary) for operational and investment costs. The majority of this funding comes from the KAP based on a formula and several distribution criteria. ${ }^{7}$ The final formula is decided annually by the Ministers of Internal Affairs, Finance (and Economy if funding is intended for investment) after suggestions from the union of local government representatives (K.E.D.K.E.). Similarly, but at a smaller scale, municipal loans (5.6\% of the total) are an additional source of funding that is dependent on

\footnotetext{
7 The criteria of apportionment consider population, accessibility and inequality characteristics such as: (a) length of water and sewage pipes, (b) length and accessibility of road network, (c) whether it is a mountainous, lowland or island municipality, (d) the existing level of social services, (e) the capacity to generate own revenues, (f) population and its seasonal variations and trends, (g) the average weather conditions and number of school classes and (h) the environmental conditions.
} 


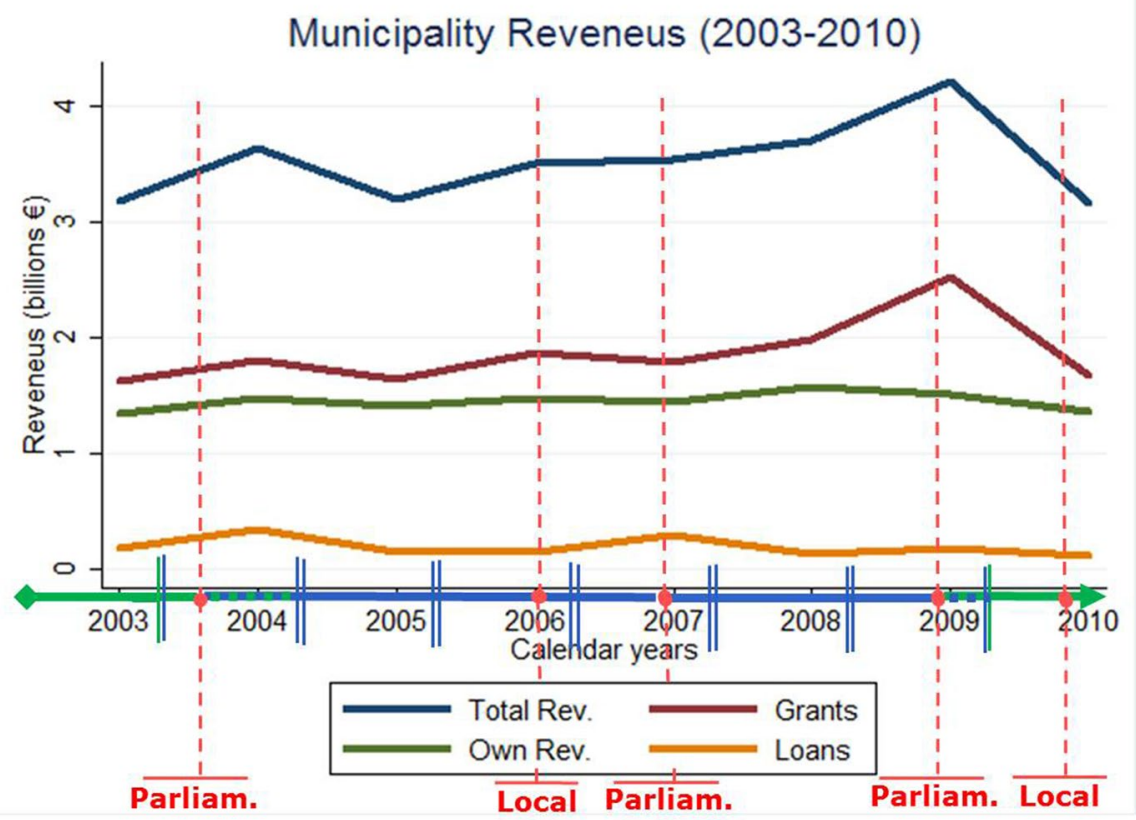

Fig. 2 Total and the three principal categories (grants, own and loans) of annual revenues of affiliated municipalities for the period 2003-2010, projected on the electoral timeline (green (light) when Social Democrats and blue (dark) when Conservatives in government), with the red lines indicating the election dates

central budget and decision making. Laws 2503/1997 and 3463/2006 allow municipalities to independently ${ }^{8}$ apply and obtain a loan from a national financial institution by using part of KAP or other special grants assigned to their budget for its repayment or guarantee.

On the other hand, 'own revenues' is a more autonomous source of income for the municipalities. They are mostly derived from user fees, charges and taxes, which have been established and defined by the central government, following specific conditions on their level and increases. Local authorities are fully responsible for their collection and therefore can enjoy some degree of freedom. Own revenues is the mechanism that allows mayors to take initiatives and acquire additional funds to either replace reduced grants or to meet municipal needs without (to some extent) the central government's approval. In contrast with government grants and loans, increasing own revenues could bear political costs for local authorities if they are to come by raising additional taxes, fees and penalties.

\footnotetext{
${ }^{8}$ Due process in obtaining a loan (the procedure followed, as well as that the amount borrowed is within limits) is guaranteed by the regional administrator (government appointed role for 2003-2010) and an independent auditing body..
} 


\subsection{Method and model}

Given the large differences in municipality size $(\mu=10691.37$, S.D. $=30522.77)$, the data on local revenues are highly skewed towards larger local authorities. In order to correct for skewness towards larger municipalities, we attempt two basic transformations on the dependent variables (total revenues, grants, loans and own revenues); we analyse either their natural logarithm (log_Total, log_Grants, log_RevOwn and log_Debt), or their ratio to total revenues (Grants Dependency, Revenue Autonomy and Debt Dependency). ${ }^{9}$

Whilst the logarithmic transformation is a standard corrective approach, commonly used in similar studies (e.g. Rodríguez-Pose et al. (2016b)), the ratio to the total has only been used to approximate fiscal decentralization (Psycharis et al. 2016). Here, total revenues are used to normalize each variable under investigation (e.g. own revenues) in order to perform a between-municipalities comparison (aligned vs. non-aligned), as well as providing evidence of municipality dependency on specific types of income (grants, own, loans). Following Psycharis et al. (2016), the ratio of own revenues to the total is named Revenue Autonomy to signal the degree to which municipality finances are independent of central government decision making. Accordingly, the ratios of government grants and loans to the total revenues are called Grants Dependency and Debt Dependency to reflect how dependent local government finances are on revenues that are not within their control. Such a normalization is superior to per-capita transformations since it accounts not only for several within-municipality heterogeneity (e.g. population, geographical characteristics, etc.) but also for intertemporal effects or shocks that could disproportionately affect municipalities (e.g. financial crisis, political shocks, Olympic Games, etc.).

Under the electoral politics prism in Greece, the main hypothesis is that because of their capacity to increase the effectiveness of vote-buying strategies, aligned municipalities enjoy preferential treatment from the government with respect to financing. It is expected that this favourable treatment will be more intense in the run-up to elections due to vote-seeking behaviours. In connection with this, it is in the interest of the incumbent party in central government to support aligned mayors in their bid to be re-elected. The fixed-effect specification on our panel data allows us to investigate the effect of political changes (at local or at national level) on the budget of municipalities (i.e. within municipalities' effect across time). Our main hypothesis can be sub-categorized as follows (for both transformations $\tau$ : $\log$ or ratio to total):

A. Municipalities receive more grants when mayors are politically aligned to the central government;

B. Municipalities receive more loans when mayors are politically aligned to the central government;

\footnotetext{
9 Although a per--capita transformation is quite common practice in this literature, in our data set such a transformation does not really lead to an accurate representation of reality, namely the largest municipalities, due to their population size, appear to be the poorest ones (see SM6 fig. S1).
} 
C. Municipalities raise equal or less own revenues when mayors are politically aligned to the central government;

D. If all the above hypotheses hold, then total revenues will be significantly higher when municipalities are aligned.

As a result, the dependent variables will be analysed in two main dimensions, namely the municipalities' political alignment and time (year). The political alignment will be captured by variable:

- aligned: a dummy variable taking value 1 when a mayor's political affiliation matches the national government's one and 0 otherwise.

In order to analyse the time dimension, two new variables are generated as follows:

- pre_parl: a dummy variable indicating the period prior to parliamentary elections. It takes value 1 for the years 2003 and 2007 and 0 for the rest.

- pre_local: a dummy variable accounting for the period before local elections held in 2006. It takes value 1 for this year and 0 for the rest.

Since the parliamentary elections were held during the first quarter of 2004 (7 March) and the second half of 2007 (16 September) (Fig. 2), it was considered appropriate to use 2003 and 2007 as the pre-election years. Assuming that the budgets are determined at the beginning of the year, an incumbent government could not expect to significantly impact the election results by pork-barrelling in 3 months (as is the case for the 2004 national election), whilst this would be possible in 9 months (as in the case of the 2007 election). In addition, pre_parl does not account for the 2009 parliamentary elections (4 October). This is because these elections were not planned (next ones expected to be in 2011) and were called for in September 2009 and with the national economy about to enter its long-lasting debt crisis. As a result, even if pork-barrelling was an option, the incumbent party would not have the time to target funding to specific municipalities. In a similar vein, 2010 has been excluded from pre_local. During this year, the country was already facing the financial crisis which had a significant impact on the level of government transfers to municipalities (Fig. 2). As a result, funding for pork barrel politics would be expected to be significantly diminished. Two robustness checks are being performed (supplementary material SM2 and SM4) in order to test these two assumptions. They largely confirm the results and provide some interesting findings on the 2008 crisis impact on distributive politics in the run-up to local elections (see Results section).

The variables of interest are the revenues of aligned municipalities during the pre-electoral years. For this reason, the following two interactions are examined:

- aligned_pre_parl: a dummy variable taking value 1 if both aligned and pre_parl are equal to 1 , and 0 otherwise. 
- aligned_pre_local: a dummy variable taking value 1 if both aligned and pre_ local are equal to 1 , and 0 otherwise.

A panel, fixed-effects econometric model is used to uncover the variation within municipalities across time whilst accounting for unobserved heterogeneity. ${ }^{10}$ The fixed effect controls for all time-invariant characteristics of municipalities. Consequently, the coefficients cannot be biased due to omitted time-stable characteristics or measurement issues. We also use regionally clustered robust standard errors to allow for intragroup correlation at the level of prefecture (the observations are independent across prefectures but not necessarily within prefectures), a model specification which minimizes the problems of heteroscedasticity and autocorrelation usually observed in panel data sets.

The main independent variables are complemented by controls for the following time-variant characteristics: (a) gover, a dummy variable to control whether different political parties have followed different policies with regards to local authority financing (i.e. focus on own revenues vs focus on grants) when they were in power; (b) $g d p \_c a p$, a continuous variable indicating the GDP/capita of the prefecture ${ }^{11}$ in which a municipality belongs. This variable aims to control for the efficiency vs equity nexus on the distribution of public resources. Considering GDP/capita as a proxy for more (or less) economically successful areas, this variable could indicate whether government grants are directed to more efficient areas or places with greater need; (c) conservative_party and (d) other_party, two dummies indicating the specific affiliation of the mayor, using social_democrats as a reference group; (e) $y r 2004$, (f) $y r 2005$, (g) yr2009 and (h) yr2010, four single-year dummies controlling for the corresponding year and using yr2008 as reference group (variables pre_parl and pre_local already account for years 2003, 2006 and 2007). 2008 is selected as a reference year since there was not any substantial political (e.g. elections) or economic (e.g. crisis, Olympic Games) shock taking place. For the same reasons, 2005 could also be used as a reference group (see supplementary material SM1 for robustness check).

Equation (1) describes the main empirical model (including interactions) of our analysis:

\footnotetext{
${ }^{10}$ Hausman test confirmed the prevalence of the fixed-effects over a random-effects model by rejecting the hypothesis that the unique errors (ui) are not correlated with the regressors. No multicollinearity has been detected in the choice of the independent variables. The only Tolerance value lower than $10 \%$ is the one of gdp_cap which does not affect any of the results. Whilst it is true that such an approach restricts the number of explanatory variables and of the corresponding results (e.g. we cannot offer insights into how the size of a municipality affects its finances), the method guarantees that results are not affected by these factors. Since the focus of the study is the impact of political alignment on municipality financing, we consider that the municipality time-invariant characteristics primarily are hard to capture in their entirety and are also secondary to the interest of the study.

${ }^{11}$ Source: Eurostat. To the best of the authors' knowledge, socio-economic indicators are unavailable for Greece for 2003-2010 below the NUTS3 level except from the Census carried out once every 10 years (and hence not offering variation in time). Prefectures are the government level immediately above the municipality level. They are NUTS3 regions and there are 51, covering the Greek territory.
} 


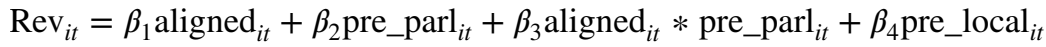

$$
\begin{aligned}
& +\beta_{5} \operatorname{aligned}_{i t} * \text { pre_local }_{i t}+\beta_{6} \text { gover }_{t}+\beta_{7} \text { gdp_cap }_{i t}
\end{aligned}
$$

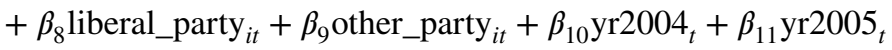

$$
\begin{aligned}
& +\beta_{12} \mathrm{yr}^{2009}+\beta_{13} \mathrm{yr}_{t} 010_{t}+\alpha_{i}+\varepsilon_{i t}
\end{aligned}
$$

where

- $\operatorname{Rev}_{\text {it }}$ is the dependent variable (log_Total, log_Grants, log_OwnRev, log_ Loans, Grants Dependency, Revenue Autonomy, or Debt Dependency), where $i=$ municipality and $t=$ time.

- $\beta_{(1-13)}$ are the coefficients of the explanatory and control variables

- $\alpha_{i}(i=1 \ldots n)$ is the unknown intercept for each municipality

- $\varepsilon_{i t}$ is the error term

\section{Results}

Table 1 reports the coefficients and corresponding standard errors (in parentheses) of the regressors for the models with dependent variables Log_Grants (A), Log Loans $^{12}$ (B), Log_OwnRev (C) and Log_Total (D). Models A-D also correspond to the four hypotheses. The difference between models subscripted with ' 1 ' and ' 2 ' is that the latter include the interaction terms aligned_pre_parl and aligned_pre_local.

The coefficients of pre_parl and pre_local are, in many cases significant, indicating that the years before elections have a statistically significant difference in funding compared to the reference year (2008). A comparison between Table 1 and the robustness check using 2005 as the reference year (SM1) suggests that the sign and size of these coefficients are influenced by the choice of the reference year.

The main interest of the study is on the interactions aligned_pre_parl and aligned_pre_local which represent municipalities when they are politically aligned to the central government and in the run-up to national and local elections, respectively. The coefficient of aligned_pre_parl is significant and positive in models $\mathrm{A}_{2}$ and $\mathrm{D}_{2}$ increasing grants and total revenues by $13 \%$ and $9.7 \%$, respectively. When aligned, municipalities receive on average about $€ 1.3$ million more grants and $€ 1.9$ million more total revenues than when they are not aligned in the pre_parl periods. Similarly, the statistically significant coefficient for aligned_pre_local in $\mathrm{A}_{2}$ suggests that municipalities also receive more grants $(6.2 \%$ or $€ 0.6$ million on average) when aligned in the run-up to local elections.

With regards to specification $B_{2}$, the statistically significant coefficient $\beta_{3}$ should be treated with caution. The large number of zero values for log_Loans (see note 13)

\footnotetext{
12 Since the sample has many municipalities (especially after 2004) with no (or negative) loans on their budget and the natural logarithm of zero is not defined, we substitute these zero values with ' 1 ' for not losing those observations. This problem does not exist when using the ratios in Table 2 .
} 


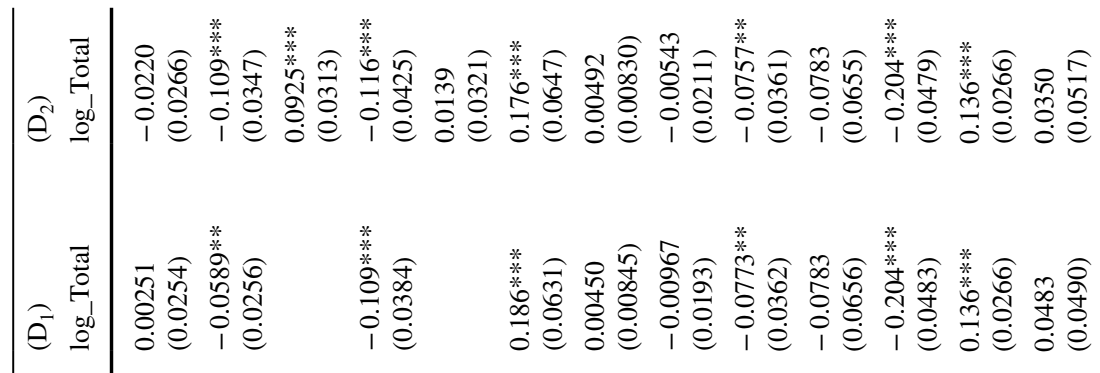

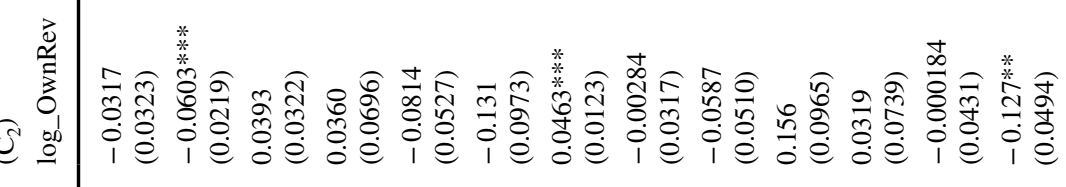

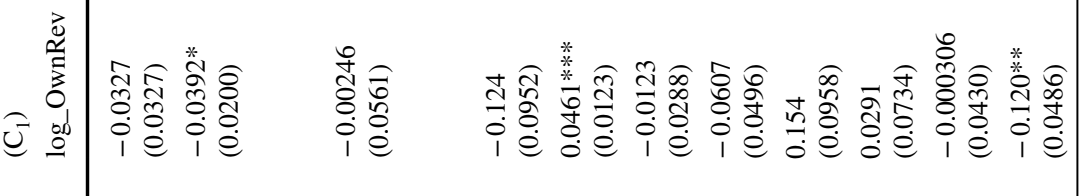

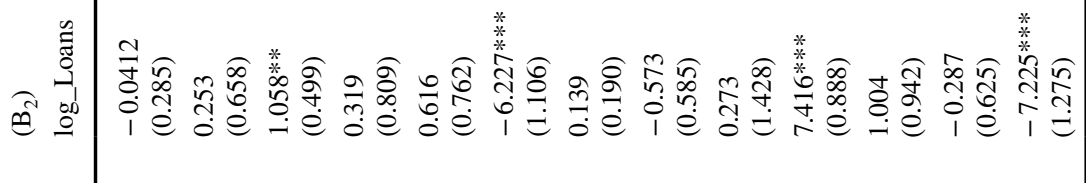

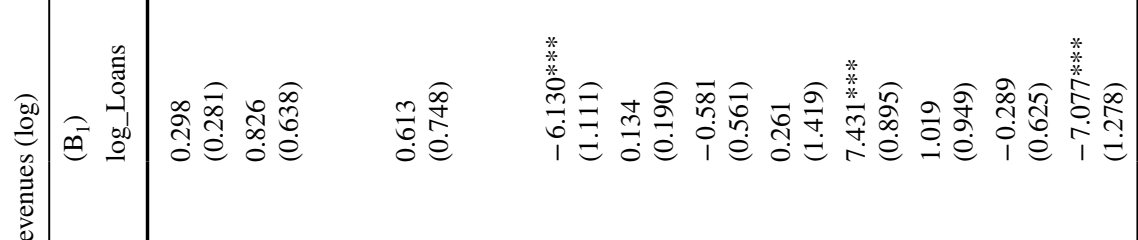

壳

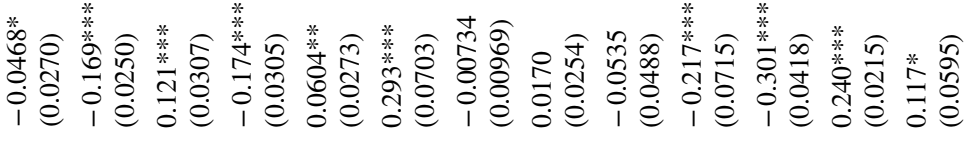

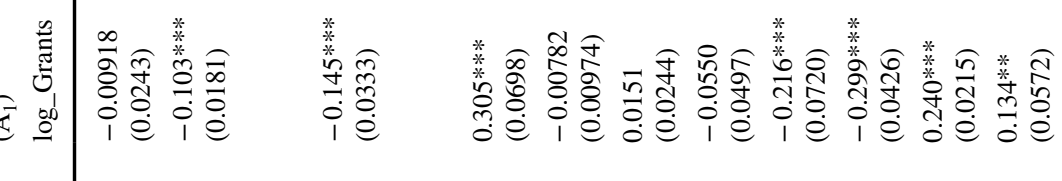

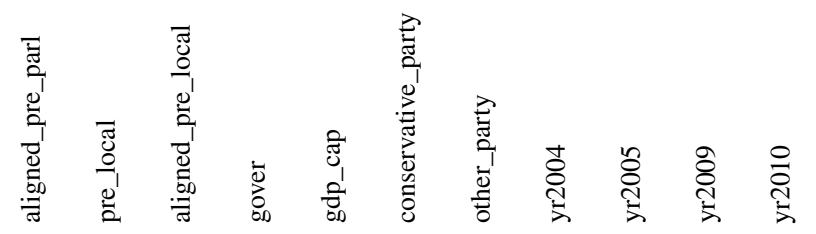




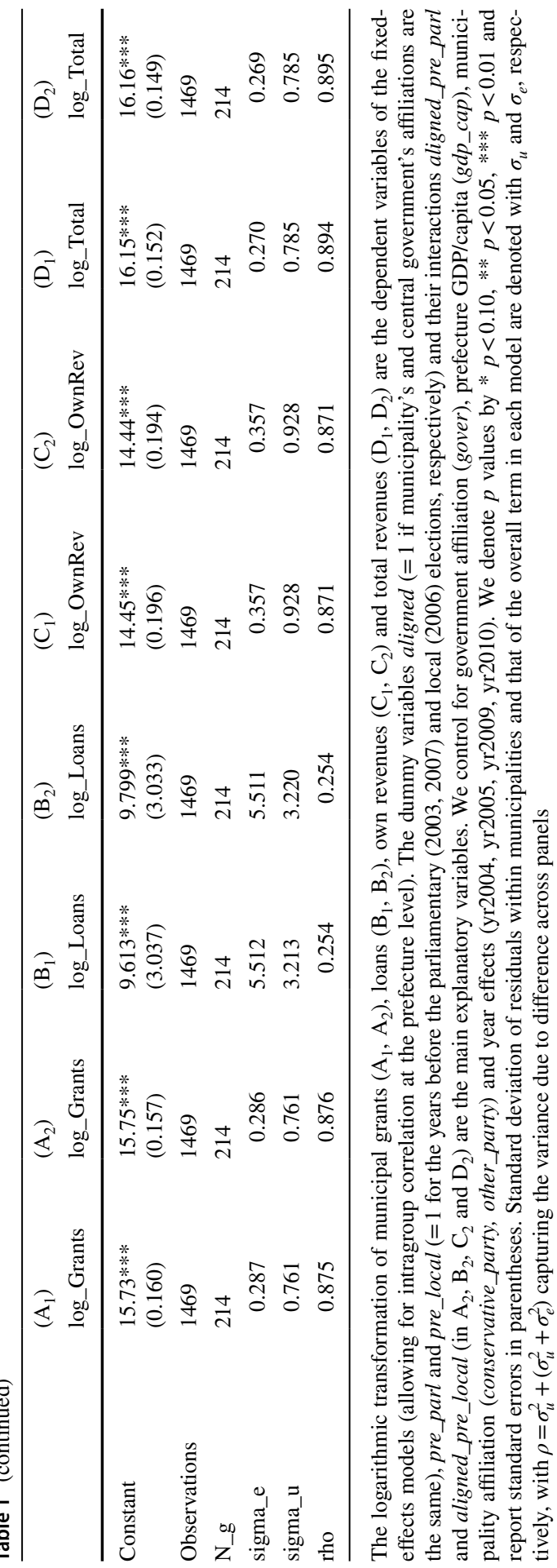




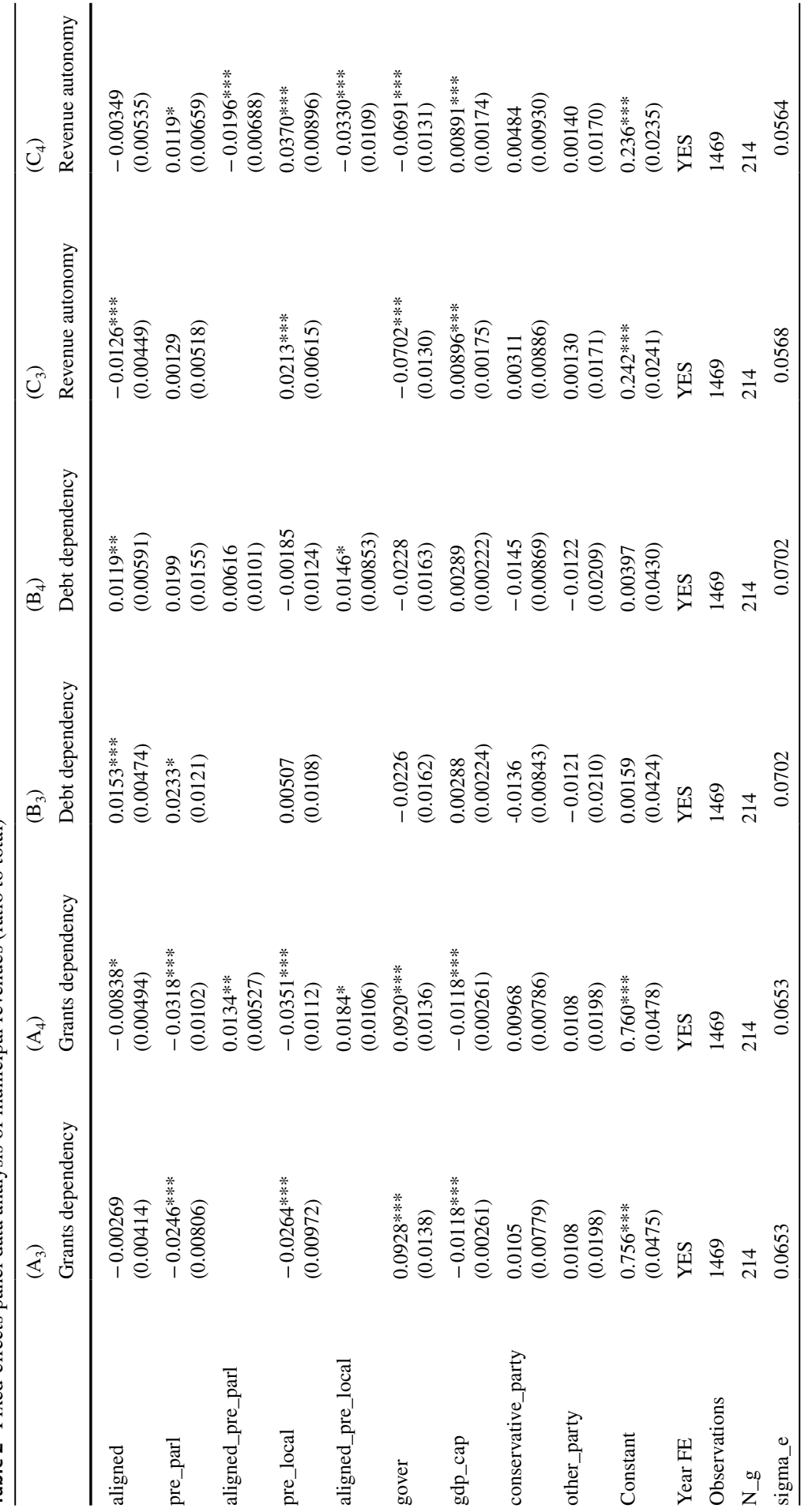




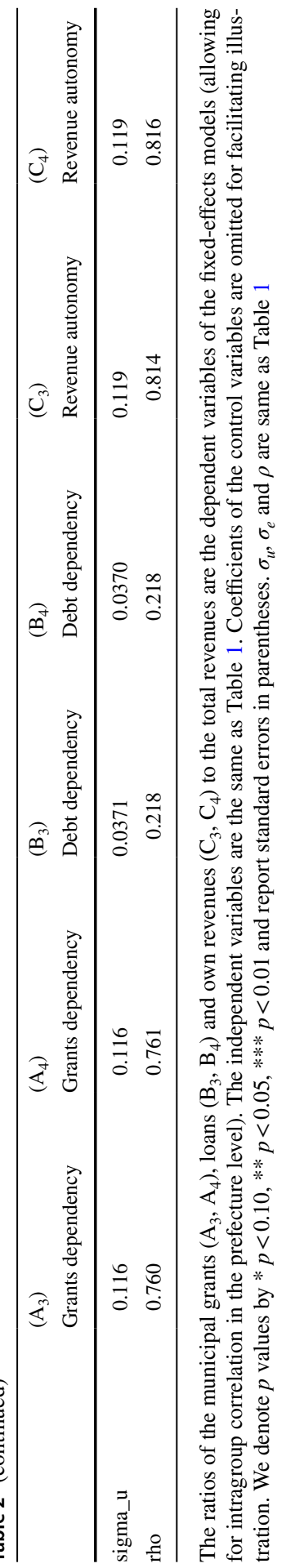


means that the size of the coefficient is inflated. Further investigation in SM3 in supplementary material shows the results of a logistic regression (fixed-effects) using the dependent dummy variable $D \_$Loans (taking the value 1 if loans $>0,0$ otherwise). We find that in pre_parl periods, the probability of a municipality to obtain a loan when it is aligned is $92 \%$ higher than when it is not.

- Result 1: In the run-up to national elections, municipalities receive more grants (A) and have greater probability in obtaining loans (B) when mayors are politically aligned to the central government. Concurrently, there is no difference in own revenues (C). As a result, municipalities obtain more total revenues (D) when they are aligned.

- Result 2: In the run-up to local elections, municipalities receive more grants (A) when mayors are politically aligned to the central government.

Our findings are particularly interesting and novel in that they identify influences on the interaction between political alignment and both the local and national electoral business cycles. They are consistent with studies in different countries that partially cover alignment and political business cycle aspects.

To the extent that political alignment reveals voting intentions at the national level (see earlier discussion on the politicization of local government elections), our results on aligned_pre_parl support the core voter hypothesis in conjunction with the political business cycle thesis. In this sense, the paper adds an electoral business cycle angle to the findings of Kauder et al. (2016) and Ansolabehere and Snyder (2006) for Germany and the USA, respectively, and evidence of a core voter bias to the results of Veiga and Pinho (2007) on the electoral business cycle in Portugal.

The positive effect of political alignment to municipal grants in the run-up to elections agrees broadly with the alignment effects on intergovernmental grants found in Solé-Ollé and Sorribas-Navarro (2008), Borck and Owings (2003), and Kauder et al. (2016) in Spain and California, respectively. More specifically, our results on the interaction between alignment and pre-local elections agree with the relevant findings of Brollo and Nannicini (2012), Livert and Gainza (2018) and Bracco et al. (2015) for Brazil, Chile and Italy, respectively. Non-aligned municipalities in pre-election periods (coefficients for pre_parl and pre_local in $\mathrm{A}_{2}$ ) are found to receive significantly lower grants echoing the negative coefficients found by Brollo and Nannicini (2012). Alignment in these years provides a positive uplift.

Attempting to explain why total revenues are not affected in pre-local elections periods, our attention is directed towards own revenues. Whilst in pre-national election periods, municipality own revenues appear to be positive, during pre-local election periods they turn negative, suggesting a substitution effect between grants and own revenues in the run-up to local elections. This could explain why total revenues are significantly different before national elections but not before local ones. However, it should be noted that the lack of statistical significance for the relevant coefficients in $\mathrm{C}_{2}$ means that the above arguments are more speculative rather than supported by econometric evidence.

The control variables also provide interesting results. Variable gover which controls whether different political parties in the national government have pursued 
different policies with regards to municipality financing suggests that one party focused more on grants and the other more on loans. Own revenues were not affected by either party. The coefficients for $g d p \_c a p$ suggest that municipalities in prefectures with higher GDP/capita generate more own revenues and hence are more autonomous, but they do not receive more grants or loans. It is probable that this reflects the limitations of using GDP/capita at the prefecture level to proxy growth levels in different municipalities rather than the lack of equity or efficiency arguments in distributing government grants.

Including 2010 in pre_local (SM2) results in losing the statistical significance of coefficients for aligned_pre_local.

- Result 3: When we include 2010 in pre_local, municipalities do not receive more grants when mayors are politically aligned in the run-up to local elections.

This could be an unseen benefit of the 2008 economic crisis in the form of reduced distributive politics activity in the run-up to local elections in 2010. It might reflect the start of a new era of reduced pork-barrelling activity or the effect of significantly restricted public finances. Unfortunately, the political turbulence that followed 2010 (multiple national elections and external supervision of public spending) makes it impossible to econometrically clarify the true reasons for this drop until more data points are collected.

Finally, we see that the coefficients of the year fixed-effects are also significant as compared to 2008 base year, indicating that time controls cannot be omitted from the analysis. In SM1 of the supplementary material, we use year 2005 as a control year and we find that the magnitude and in some cases even the sign of the other year variables, including pre_parl and pre_local, are also changing. However, the size and the significance of our two interaction terms remained unchanged, highlighting the robustness of our results.

The analysis of Table 1 is repeated in Table 2 using Grants Dependency, Debt Dependency and Revenue Autonomy as the dependent variables which are the ratios of grants, loans and own revenues to the total revenues. The findings on the effect of aligned_pre_parl and aligned_pre_local on grants are confirmed. In the run-up to national and local elections, aligned municipalities show statistically significant differences from non-aligned ones in the proportion of grants to their total revenues. In particular, the coefficient of aligned_pre_parl in $\mathrm{A}_{4}$ suggests that in pre-election (parliamentary) years, the share of grants to the total revenues is $1.34 \%$ higher for aligned municipalities. Similarly, the coefficients for aligned_pre_local in $\mathrm{A}_{4}$ and $\mathrm{B}_{4}$ point to an increase of $1.84 \%$ in the share of grants to the total revenues and of $1.46 \%$ in the share of loans to the total.

These results confirm that the increase observed at the logarithmic transformation is significant even in terms of proportionality, meaning that it is not just that aligned municipalities receive more grants in pre-election periods, but also that these are disproportionately increased against other revenues, thus increasing the dependency of aligned municipalities on government grants and loans. Moreover, the share of loans to the total revenues for aligned municipalities is $1.53 \%$ higher than the corresponding one for non-aligned municipalities, irrespective of the period under 
examination. Finally, with regards to the Revenue Autonomy, the negative and significant coefficients of aligned $\left(\mathrm{C}_{3}\right)$, aligned_pre_parl and aligned_pre_local $\left(\mathrm{C}_{4}\right)$ mirror the results on specifications $\mathrm{A}_{3}-\mathrm{B}_{4}$ and their effect on total revenues (Grants Dependency +Debt Dependency+Revenue Autonomy=1) and, similarly, the decreasing autonomy of municipalities.

\section{Concluding remarks}

Greece is a country that suffered for many years from lack of government efficiency related to electoral politics. This paper focused on the mediating effect of local government and the electoral business cycle on the central government's pursuit of tactical distribution of public goods. It contributes to the literature of electoral politics in Greece and internationally by highlighting the role of political alignment between different tiers of government during the electoral business cycle and by examining municipality financing which reflects a more immediate resource allocation than investments.

In line with existing theoretical contributions, we hypothesized that if an incumbent government is engaging in vote-buying, it is more efficient to do it via local government financing since municipalities allow more granular (within constituency) targeting of voters. Simultaneously, the municipality level offers a better knowledge of the voter base and, to the extent that it is politically aligned to the government, it can significantly increase the efficiency of such activities. Considering these transfers within the electoral cycle, it is expected that in the run-up to elections, aligned municipalities will receive preferential financing.

We study these hypotheses utilizing a rich panel data set combining 8 years (2003-2010) of municipality funding and election results. We employ a range of econometric methods to address heterogeneity in the nature of the study and the data itself (see for example the 0 values of loans and the use of regionally clustered robust standard errors). Our paper finds evidence that electoral politics played a role in the distribution of government grants to municipalities.

In particular, the results are novel in finding statistically significant differences in the interaction of alignment effects in the run-up to both national and local elections in Greece. They suggest that aligned municipalities receive approximately $13 \%$ more grants and have $9.7 \%$ more total revenues in the run-up to national elections. On average, these figures correspond to $€ 1.3$ million more grants and $€ 1.9$ million more total revenues, respectively. Concurrently, aligned municipalities show increased grant receipts $(6.2 \%, € 0.6$ million on average) compared to non-aligned ones during pre-local election years. The results are confirmed by a range of robustness checks involving changes in the reference year to 2005, as well as the inclusion of 2010 in pre_local and 2009 in pre_parl. We also run a random-effects panel data model using the Hausman-Taylor estimator to account for dynamic dependency (Frick and Rodríguez-Pose 2018). The outcomes of the robustness checks (see supplementary material SM1, SM2, SM4 and SM5) largely confirm the results of the main analysis, lending credence to the hypothesis that political considerations and in particular the 
alignment between government levels and the electoral cycle do affect the allocation of intergovernmental grants.

The results are relevant to the current structure of spatial governance in Greece since (as discussed in the Greek case section) the 'Kalikratis' restructuring was based on the principle of improving efficiency and cutting costs rather than re-scaling (Chorianopoulos 2012). They are also relevant to most countries with multi-level governance systems and strong vertical networking dependency, as well as countries with strong traditions of clientelism and recently re-established representative governance structures such as the Central and Easter European Countries.

This significant misallocation of resources can impede long-term local economic growth via at least two channels. The first is the direct allocation of public goods and the associated conditions for growth with Luca (2018) suggesting a strong link between allocations and subsequent growth in Turkey. The second is an indirect channel based on the Brollo et al. (2013) who suggest that distributive politics and corruption signals decrease the quality of candidates in municipal elections leading to a vicious cycle of declining quality of governance. The results of this study call for an increase in decentralization of local government financing for two main reasons.

First and foremost, the need to reduce pork barrel politics calls for the greater empowerment of local government in raising their own revenues. The size of government transfers encourages their misuse for electoral gains, whilst it can create a rent-seeking environment where local authorities compete for providing the best (electoral) services to the incumbent party rather than the populations they represent. In addition, the fact that the majority of the grants we consider are allocated using a formula suggests that propositions to move from discretionary to more formula-based distributions (see Kauder et al. (2016)) may be inadequate in Greece and other countries with low performance on government efficiency.

Secondly, being dependent on government transfers increases vertical dependency and is detrimental to an environment that needs more local innovation in public service reform, with new ways of generating income and more efficient delivery of public services. As a result, minimizing local government dependency on the state can achieve multiple benefits by reducing the opportunities for pork-barrelling and improving innovation and efficiency at the local level.

Finally, the paper is subject to limitations, some of which open avenues for further research. Whilst the Greek electoral system in our study period offers significant advantages (concurrent elections for all municipalities, variation in parties in both the upper- and lower-tier government levels), it does not allow for the examination of the influences considered in papers such as Carozzi and Repetto (2016), Gonschorek et al. (2018) and Dalle Nogare and Kauder (2017). ${ }^{13}$ It is unclear from our study whether mayors are unintentionally involved in this misallocation of resources

\footnotetext{
13 The existence of multi-member parliamentary constituencies which do not correspond to municipal boundaries makes a study of the influence of home town bias (a la Carozzi and Repetto (2016)) particularly difficult whilst there is no term limits in either lower- or upper-tier government levels in Greece as is the case for Gonschorek et al (2018) and Dalle Nogare and Kauder (2017).
} 
or whether they are willing volunteers. Due to the top-down nature of municipality financing, it is unlikely that they hold the power to significantly lobby (Dalle Nogare and Kauder 2017) central government beyond their partisan credentials. However, further examination of these matters, together with the experience of mayors in the office, the effectiveness of these allocations as well as the way municipalities use these finances forms important questions for further research.

Acknowledgements The authors would like to thank Raquel Ortega-Argiles and Geoffrey Hewings as well as the participants of the Regional Studies Association conference in 2019, Global Conference on Economic Geography in 2018 and European Regional Science Association Congress in 2018 and 2019 for helpful comments on earlier drafts. The usual disclaimer applies.

Funding Kitsos would like to acknowledge seed funding from the University of Birmingham and the Birmingham Business School in order to conduct the research in collaboration with Antonios Proestakis.

Open Access This article is licensed under a Creative Commons Attribution 4.0 International License, which permits use, sharing, adaptation, distribution and reproduction in any medium or format, as long as you give appropriate credit to the original author(s) and the source, provide a link to the Creative Commons licence, and indicate if changes were made. The images or other third party material in this article are included in the article's Creative Commons licence, unless indicated otherwise in a credit line to the material. If material is not included in the article's Creative Commons licence and your intended use is not permitted by statutory regulation or exceeds the permitted use, you will need to obtain permission directly from the copyright holder. To view a copy of this licence, visit http://creativecommons.org/licen ses/by/4.0/.

\section{References}

Ansolabehere S, Snyder JM (2006) Party control of state government and the distribution of public expenditures*. Scand J Econ 108:547-569. https://doi.org/10.1111/j.1467-9442.2006.00470.x

Balaguer-Coll MT, Prior D, Tortosa-Ausina E (2010) Decentralization and efficiency of local government. Ann Reg Sci 45:571-601. https://doi.org/10.1007/s00168-009-0286-7

Bartolini D, Santolini R (2012) Political yardstick competition among Italian municipalities on spending decisions. Ann Reg Sci 49:213-235. https://doi.org/10.1007/s00168-011-0437-5

Borck R, Owings S (2003) The political economy of intergovernmental grants. Reg Sci Urban Econ 33:139_ 156. https://doi.org/10.1016/S0166-0462(02)00005-4

Bracco E, Lockwood B, Porcelli F, Redoano M (2015) Intergovernmental grants as signals and the alignment effect: theory and evidence. J Public Econ 123:78-91. https://doi.org/10.1016/j.jpubeco.2014.11.007

Brollo F, Nannicini T (2012) Tying your enemy's hands in close races: the politics of federal transfers in Brazil. Am Polit Sci Rev 106:742-761. https://doi.org/10.1017/S0003055412000433

Brollo F, Nannicini T, Perotti R, Tabellini G (2013) The Political Resource Curse. Am Econ Rev 103:17591796. https://doi.org/10.1257/aer.103.5.1759

Carozzi F, Repetto L (2016) Sending the pork home: birth town bias in transfers to Italian municipalities. J Public Econ 134:42-52. https://doi.org/10.1016/j.jpubeco.2015.12.009

Case A (2001) Election goals and income redistribution: recent evidence from Albania. Eur Econ Rev 45:405-423. https://doi.org/10.1016/S0014-2921(00)00078-7

Castells A, Solé-Ollé A (2005) The regional allocation of infrastructure investment: the role of equity, efficiency and political factors. Eur Econ Rev 49:1165-1205. https://doi.org/10.1016/j.euroecorev .2003 .07 .002

Chardas A (2014) The interplay between austerity, domestic territorial reform and European Union Cohesion Policy: multi-level governance and the application of the partnership principle in Greece. Eur Urban Reg Stud 21:432-444. https://doi.org/10.1177/0969776413504944

Chorianopoulos I (2012) State spatial restructuring in Greece: forced rescaling, unresponsive localities. Eur Urban Reg Stud 19:331-348. https://doi.org/10.1177/0969776411430351 
Cox GW, McCubbins MD (1986) Electoral politics as a redistributive game. J Polit 48:370-389. https://doi. org $/ 10.2307 / 2131098$

Dahlberg M, Johansson E (2002) On the vote-purchasing behavior of incumbent governments. Am Polit Sci Rev 96:27-40. https://doi.org/10.1017/S0003055402004215

Dalle Nogare C, Kauder B (2017) Term limits for mayors and intergovernmental grants: evidence from Italian cities. Reg Sci Urban Econ 64:1-11. https://doi.org/10.1016/j.regsciurbeco.2017.01.004

Diaz-Cayeros A, Estévez F, Magaloni B (2007) Strategies of vote buying: social transfers, democracy and welfare in Mexico. Stanford University, Stanford

Dixit A, Londregan J (1996) The determinants of success of special interests in redistributive politics. J Polit 58:1132-1155. https://doi.org/10.2307/2960152

Drazen A, Eslava M (2010) Electoral manipulation via voter-friendly spending: theory and evidence. J Dev Econ 92:39-52. https://doi.org/10.1016/j.jdeveco.2009.01.001

Dubois E, Paty S (2010) Yardstick competition: Which neighbours matter? Ann Reg Sci 44:433-452. https:// doi.org/10.1007/s00168-008-0273-4

Golden M, Min B (2013) Distributive politics around the world. Annu Rev Polit Sci 16:73-99

Gonschorek GJ, Schulze GG, Sjahrir BS (2018) To the ones in need or the ones you need? The political economy of central discretionary grants-empirical evidence from Indonesia. Eur J Polit Econ 54:240260. https://doi.org/10.1016/j.ejpoleco.2018.04.003

Grossman PJ (1994) A political theory of intergovernmental grants. Public Choice 78:295-303

Kauder B, Potrafke N, Reischmann M (2016) Do politicians reward core supporters? Evidence from a discretionary grant program. Eur J Polit Econ 45:39-56. https://doi.org/10.1016/j.ejpoleco.2016.09.003

Kaufmann D, Kraay A, Mastruzzi M (2013) World governance indicators. The World Bank, Washington

Lambrinidis M, Psycharis Y, Rovolis A (2005) Regional allocation of public infrastructure investment: the case of Greece. Reg Stud 39:1231-1244. https://doi.org/10.1080/00343400500390057

Lindbeck A, Weibull JW (1987) Balanced-budget redistribution as the outcome of political competition. Public Choice 52:273-297

Livert F, Gainza X (2018) Distributive politics and spatial equity: the allocation of public investment in Chile. Reg Stud 52:403-415. https://doi.org/10.1080/00343404.2017.1309013

López FA, Martínez-Ortiz PJ, Cegarra-Navarro J-G (2017) Spatial spillovers in public expenditure on a municipal level in Spain. Ann Reg Sci 58:39-65. https://doi.org/10.1007/s00168-016-0780-7

Luca D (2018) Picking winners at the ballot box: votes and local economic growth in Turkey. In: Economic research forum working papers, vol 1232

Luca D, Rodríguez-Pose A (2015) Distributive politics and regional development: assessing the territorial distribution of Turkey's public investment. J Dev Stud 51:1518-1540. https://doi.org/10.1080/00220 388.2015.1028536

Lyberaki A, Tsakalotos E (2002) Reforming the economy without society: social and institutional constraints to economic reform in post-1974 Greece. New Polit Econ 7:93-114

Musgrave R (1959) The theory of public finance; a study in public economics. McGraw Hill, New York

Nordhaus WD (1975) The political business cycle. Rev Econ Stud 42:169-190

Psycharis Y, Zoi M, Iliopoulou S (2016) Decentralization and local government fiscal autonomy: evidence from the Greek municipalities. Environ Plan C Govern Policy 34:262-280. https://doi. org/10.1177/0263774X15614153

Rodríguez-Pose A, Psycharis Y, Tselios V (2016a) Liberals, socialists, and pork-barrel politics in Greece. Environ Plan A 48:1473-1492

Rodríguez-Pose A, Psycharis Y, Tselios V (2016b) Politics and Investment: examining the territorial allocation of public investment in Greece. Reg Stud 50:1097-1112. https://doi.org/10.1080/00343 404.2015.1009027

Rogoff K (1990) Equilibrium political budget cycles. Am Econ Rev 80:21-36

Rogoff K, Sibert A (1988) Elections and macroeconomic policy cycles. Rev Econ Stud 55:1-16. https://doi. org/10.2307/2297526

Shi M, Svensson J (2006) Political budget cycles: Do they differ across countries and why? J Public Econ 90:1367-1389. https://doi.org/10.1016/j.jpubeco.2005.09.009

Solé-Ollé A (2013) Inter-regional redistribution through infrastructure investment: Tactical or programmatic? Public Choice 156:229-252. https://doi.org/10.1007/s11127-011-9896-6

Solé-Ollé A, Sorribas-Navarro P (2008) The effects of partisan alignment on the allocation of intergovernmental transfers. Differ Differ Estim Spain J Public Econ 92:2302-2319. https://doi.org/10.1016/j.jpube co.2007.06.014 
Veiga LG, Pinho MM (2007) The political economy of intergovernmental grants: evidence from a maturing democracy. Public Choice 133:457-477. https://doi.org/10.1007/s11127-007-9208-3

Veiga LG, Veiga FJ (2007) Political business cycles at the municipal level. Public Choice 131:45-64. https:// doi.org/10.1007/s11127-006-9104-2

Publisher's Note Springer Nature remains neutral with regard to jurisdictional claims in published maps and institutional affiliations. 